\title{
Pengembangan Media Pembelajaran Matakuliah Metode Numerik dengan Implementasi Scilab Berbantuan Software Latex
}

\author{
Nurul Arfinanti \\ Pendidikan Matematika, UIN Sunan Kalijaga Yogyakarta \\ Jalan Marsda Adisucipto Yogyakarta \\ Email:nurul.arfianti@uin-suka.ac.id
}

\section{Article History:}

Received: 28-09-2018; Received in revised form: 04-12-2018; Accepted: 15-12-2018; Available online: 30-12-2018

\begin{abstract}
The aim of this study is to develop media for learning using Scilab and Latex in Numerical Methods course. Numerical methods is a course which use a lot of numerical symbol. Scilab is used to solve a numerical problem, and Latex is used to write subject matter with a lot of numerical symbols. This study use Research and Development (R\&D) models by Thiagarajan which compreised in three steps: defining, designing, and developing. The data were collect from two expert in content, two expert in media for learning, and 11 responses from students. Data were analyzed using qualitative method. The results of this study showed that the media for learning has fulfilled the criteria of the quality determined. This is based on the results of the assessment of content's experts which get percentage of idealism score 94,53 (very good), the results of the assessment of media for learning's experts which get percentage of idealism score 86,46 (very good), student response results with an average percentage of idealization score of 89.325 (very good), and students had fulfilled lesson learnead which designed.
\end{abstract}

Keywords: Media for Learning; Numerical Methods Course; Scilab; Latex

Abstrak

Penelitian ini bertujuan untuk mengembangkan media pembelajaran matakuliah Metode Numerik dengan implementasi Scilab berbantuan software Latex. Metode Numerik merupakan matakuliah yang banyak melibatkan simbol dan angka tetapi belum tersedia media pembelajarannya. Inovasi yang dilakukan dalam penelitian ini berupa penggunaan freeware Scilab dan Latex dalam pembuatan media pembelajarannya. Penelitian ini menggunakan metode penelitian dan pengembangan ( $R \& D)$ yang dikembangkan oleh Thiagarajan, yang meliputi tahap define (pendefinisian), design (perancangan), dan develop (pengembangan). Data dikumpulkan dari dua orang ahli materi, dua orang ahli media, dan respon dari 11 mahasiswa. Analisis data menggunakan teknik deskriptif kuantitatif. Hasil penelitian menunjukkan bahwa media pembelajaran yang dikembangkan telah memenuhi kriteria kualitas yang ditetapkan. Hal ini didasarkan pada hasil penilaian dari ahli materi 
yang memperoleh persentase keidealan skor rata-rata 94,53 (sangat baik), hasil penilaian dari ahli media yang memperoleh persentase keidealan skor rata-rata 86,46 (sangat baik), hasil respon mahasiswa dengan persentase keidealan rata-rata skor sebesar 89,325 (sangat baik), serta penguasaan mahasiswa terhadap capaian pembelajaran telah dinyatakan lulus semuanya (nilai minimal 65 dan rata-rata 80,82).

Kata Kunci: Media Pembelajaran; Metode Numerik; Scilab; Latex.

\section{Pendahuluan}

Peradaban manusia terus berkembang seiring dengan berkembangnya teknologi informasi dan komunikasi. Dalam menyikapi perkembangan dan kemajuan Information and Communication Technologies (ICT) tersebut, para dosen dan guru dituntut untuk menguasai teknologi (ICT) agar dapat mengembangkan materi-materi pembelajaran berbasis ICT dan memanfaatkan ICT sebagai media pembelajaran. Tujuannya adalah untuk memberikan kemudahan dan kesempatan yang lebih luas kepada pebelajar dalam belajar.

Berbagai penelitian tentang penggunaan teknologi dalam dunia pendidikan terus dilakukan sebagai upaya untuk meningkatkan kualitas pembelajaran. Beberapa diantaranya adalah pengembangan modul elektronik berbasis web sebagai alternatif dalam pembelajaran fisika ${ }^{1}$. Penelitian lainnya mengembangkan multimedia pembelajaran berbasis scientific approach terintegrasi dengan nilai karakter. Multimedia yang dikembangkan adalah multimedia interaktif dimana pengguna (user) dapat mengontrol pengoperasian program sesuai yang dikehendakinya. Paparan hasil-hasil penelitian ini menunjukkan bahwa teknologi banyak digunakan dalam mengembangkan media pembelajaran ${ }^{2}$.

Selama ini yang banyak digunakan dalam membuat media pembelajaran baik di sekolah menengah maupun di perguruan tinggi adalah slide Power Point. Slide Power Point banyak dipilih karena instalasi yang mudah dan software biasanya sudah terinstal serta mudah dalam penggunaannya. Penelitian lainnya menunjukan bahwa penggunaan Power Point sebagai media pembelajaran dapat meningkatkan hasil belajar mahasiswa $^{3}$. Meskipun demikian, ada beberapa kelemahan slide Power Point,

\footnotetext{
1 Suyoso Suyoso and Sabar Nurohman, "Pengembangan Modul Elektronik Berbasis Web Sebagai Media Pembelajaran Fisika," Jurnal Kependidikan: Penelitian Inovasi Pembelajaran 44, no. 1 (June 6, 2014), https://doi.org/10.21831/jk.v44i1.2193.

2 Suyantiningsih, Isniatun Munawaroh, and Sisca Rahmadona, "Pengembangan Multimedia Pembelajaran Berbasis Scientific Approach Terintegrasi Nilai Karakter Untuk Siswa Sekolah Dasar Di Yogyakarta," Jurnal Kependidikan: Penelitian Inovasi Pembelajaran 46, no. 1 (July 21, 2016): 1-13, https://doi.org/10.21831/jk.v46i1.9571.

3 Maryatun Maryatun, "Pengaruh Penggunaan Media Program Microsoft Powerpoint Terhadap Hasil Belajar Strategi Promosi Pemasaran Mahasiswa Semester 2 Program Studi
} 
salah satunya adalah sulit dalam menuliskan rumus-rumus atau simbolsimbol matematika.

Metode Numerik merupakan salah satu matakuliah wajib yang diajarkan pada Program Studi Pendidikan Matematika Universitas Islam Negeri Sunan Kalijaga dengan bobot 3 SKS. Pada matakuliah ini dikaji beberapa metode numerik untuk menyelesaikan berbagai persoalan matematika yang sulit dipecahkan dengan cara analitis seperti, mencari akar persamaan non linear, interpolasi, diferensial, integral, dan persamaan diferensial sederhana. Dengan memperhatikan deskripsi matakuliah tersebut, maka perlu dipertimbangkan media pembelajaran yang sesuai untuk membelajarkan matakuliah Metode Numerik. Media pembelajaran untuk matakuliah Metode Numerik harus dapat menampilkan formula matematika dengan jelas. Oleh karena itu, diperlukan software yang tepat untuk membuat media pembelajaran pada matakuliah Metode Numerik yang dapat menampilkan formula matematika dengan baik.

Penggunaan software pada kegiatan praktikum beberapa matakuliah terkadang juga mengalami permasalahan. Permasalahan yang muncul di beberapa perguruan tinggi terkait dengan penggunaan teknologi dalam kegiatan praktikum perkuliahan adalah tentang keberadaan lisensi dari software atau perangkat lunak yang digunakan. Kenyataan di lapangan menunjukkan bahwa tidak mudah membeli lisensi software untuk kegiatan praktikum dikarenakan mata anggaran yang tidak tersedia untuk pembelian lisensi software praktikum. Hal ini tentu saja perlu menjadi perhatian, sebab lisensi sangat penting khususnya untuk dunia akademik dan dunia industri. Selain itu perlu dipikirkan bahwa kegiatan praktikum harus tetap berjalan dengan segala keterbatasan yang ada. Solusi yang dapat ditawarkan untuk menyelesaikan permasalahan ini adalah mencari software atau perangkat lunak dengan fungsi serupa yang lisensinya tidak berbayar atau gratis.

Latex adalah bahasa markup atau sistem penyiapan dokumen untuk peranti lunak. Latex merupakan program komputer yang digunakan untuk membuat typesetting suatu dokumen, atau membuat formula matematika. Latex memungkinkan penulis/penggunanya untuk melakukan typesetting dan mencetak hasil kerjanya dalam bentuk tipografi yang terbaik. Oleh karenanya Latex paling banyak digunakan oleh para matematikawan, ilmuwan, insinyur, akademisi, dan profesional lainnya. Software ini dapat diunduh secara gratis melalui laman https://www.Latex-project.org.

Latex memiliki beberapa keunggulan, diantaranya adalah sebagai berikut: (a) memiliki format dokumen yang terstruktur sehingga membuat

Pendidikan Ekonomi Universitas Muhammadiyah Metro Tahun Ajaran 2014/2015," PROMOSI: Jurnal Program Studi Pendidikan Ekonomi 3, no. 1 (2015), https://doi.org/10.24127/ja.v3i1.139. 
dokumen terlihat sangat profesional dan sempurna, (b) segala jenis formula matematis dapat dituliskan dengan mudah, (c) list gambar, list tabel, daftar pustaka, footnote bahkan daftar isi dapat secara otomatis dibuat oleh program, dan (d) Latex melatih dan memaksa pengguna untuk membuat dokumen dengan struktur yang baik dan benar, sehingga tidak terjadi kerancuan dalam penulisan. Selain keunggulan tersebut, ada satu lagi keunggulan Latex yang paling penting, yaitu dapat diperoleh secara gratis atau lisensinya bebas biaya.

Meskipun Latex memiliki sederet kelebihan, tetapi juga memiliki beberapa kelemahan. Kelemahan yang pertama adalah sangat sulit untuk menuliskan dokumen yang tidak terstruktur. Dengan kata lain, dokumen yang dapat dibuat haruslah dokumen yang memiliki struktur yang jelas. Kelemahan lainnya adalah memerlukan kecerdasan manusia. Hal ini dikarenakan dalam proses penulisannya memerlukan kemampuan koding dari pengguna.

Selain persoalan pemilihan software yang digunakan dalam menampilkan konten, matakuliah metode numerik juga memberikan tantangan lain khususnya dalam memilih software yang digunakan dalam membelajarkan berbagai macam metode atau algoritma yang dikaji dalam matakuliah tersebut. Software yang digunakan selama ini adalah Matlab. Matlab merupakan salah satu software yang dapat digunakan untuk membantu masalah numerik. Kelebihan software ini dibandingkan dengan alat hitung lainnya yaitu software Matlab dapat membantu visualisasi grafik dan juga membantu melatih kemampuan penalaran mahasiswa. Meskipun demikian software ini memiliki kekurangan yaitu kapasitasnya yang besar sehingga terlalu memakan tempat pada laptop atau personal computer (PC) dan juga berbayar. Setting perkuliahan untuk matakuliah metode numerik tidak memungkinkan untuk melakukan penggunaan komputer pada laboratorium komputer dikarenakan jumlah mahasiswa yang besar pada setiap kelasnya. Untuk itu, diperlukan software yang tepat dan tidak memerlukan tempat yang besar pada laptop atau PC. Salah satu software yang dapat digunakan untuk implementasi metode-metode yang ada pada matakuliah metode numerik dalam Scilab.

Scilab merupakan salah satu perangkat lunak yang lisensinya bebas biaya. Perangkat lunak ini hampir menyerupai Matlab, sebagai sebuah program interaktif untuk komputasi numerik dan visualisasi data. Matlab merupakan salah satu software yang dapat membantu meningkatkan kemampuan menyelesaikan masalah numerik mahasiswa ${ }^{4}$. Hasil penelitian yang telah dilakukan oleh Sobirudin juga menunjukkan bahwa mahasiswa

4 Dindin Sobiruddin, "Penerapan Software MATLAB Terhadap Kemampuan Menyelesaikan Masalah Numerik Mahasiswa Jurusan Pendidikan Matematika," Paradikma Jurnal Pendidikan Matematika 8, no. 1 (April 28, 2015), https://doi.org/10.24114/paradikma.v8i1.3349. 
memberikan respon yang positif terhadap penggunaan software Matlab dalam pembelajaran metode numerik. Salah satu kelemahan dari perangkat lunak Matlab adalah tidak dapat diunduh secara gratis atau harus membayar. Hal ini berbeda dengan Scilab yang dapat diunduh secara gratis pada laman http://www.scilab.org.

Scilab adalah perangkat lunak yang lisensinya bebas biaya dan open source untuk komputasi numerik yang sering digunakan dalam bidang sains dan teknik. Perangkat lunak ini hampir menyerupai Matlab, sebagai sebuah program interaktif untuk komputansi numerik dan visualisasi data ${ }^{5}$. Scilab dapat diinstal pada PC atau laptop dengan sistem operasi GNU / Linux, Mac OS $\mathrm{X}$ dan Windows XP/Vista/7/8. Scilab dikembangkan oleh INRIA dan ENPC dari Perancis, dan selanjutnya dikelola oleh konsorsasium Scilab. Untuk mendapatkan perangkat lunak ini, kita dapat mengunduhnya melalui laman http://www.scilab.org.

Scilab pada awalnya dikembangkan untuk menyelesaikan permasalahan sistem aljabar linear simultan secara numerik, yang kemudian digunakan untuk menyelesaikan masalah numerik lainnya yang lebih kompleks. Dasar dari penyelesaian sistem persamaan aljabar linear simultan adalah matriks. Software Scilab menggunakan bahasa pemrograman tingkat tinggi yang memungkinkan akses data ke tingkat lanjut, dapat mencakup ratusan fungsi matematika, serta dapat digunakan untuk menggambar grafik dua dimensi dan tiga dimensi.

Ada beberapa kegunaan dari software Scilab, diantaranya yaitu: (1) pada bidang matematika dan terapan, yaitu digunakan untuk melakukan berbagai operasi matematika dan analisis data yang sering ditemukan pada bidang teknik dan sains. (2) Menvisualisasikan gambar dalam 2D dan 3D, yaitu berfungsi untuk memvisualisasikan data dalam berbagai jenis plot dan grafik (2D dan 3D). Kegunaan untuk optimasi, yaitu membuat algoritma untuk memcahkan masalah optimasi kontinu dan diskrit tanpa kendala dan tidak terbatas. Kegunaan di bidang Statistik, yaitu sebagai alat untuk analisis data dan pemodelan. Pada bidang desain dan analisis sistem kontrol, Scilab digunakan untuk membuat algoritma dan alat standar dalam studi sistem kontrol. Pada pemrosesan sinyal, digunakan untuk memvisualisasikan, analisis dan filter sinyal dalam domain waktu dan frekuensi. Pada pengembangan aplikasi, dapat digunakan untuk meningkatkan fungsi asli Scilab dan mengatur pertukaran data dengan alat eksternal. Selanjutnya pada bidang Fisika, yaitu dapat digunakan untuk pemodelan sistem mekanis, sirkuit hidrolik, dan sistem kontrol. 2010).

${ }^{5}$ Setia Budi Sasongko, Metode Numerik Dengan Scilab (Yogyakarta: Andi Offset, 
Berdasarkan hal tersebut maka peneliti melakukan penelitian "Pengembangan Media Pembelajaran Matakuliah Metode Numerik dengan Implementasi Scilab Berbantuan Software Latex". Dengan media pembelajaran yang dikembangkan tersebut, dihasilkan media pembelajaran matakuliah metode numerik yang berkualitas.

\section{Metode}

Penelitian ini menggunakan model Research and Development (R\&D), yang dikembangkan oleh Thiagarajan. Langkah-langkah penelitian dan pengembangan tersebut disingkat dengan 4D, yang merupakan perpanjangan dari Define, Design, Development, dan Disseminate ${ }^{6}$. Dalam penelitian ini langkah-langkah tersebut dimodifikasi menjadi tiga langkah (3D model), yaitu define, design, dan develop.

Penelitian ini melibatkan subjek ujicoba 11 orang mahasiswa semester 4 tahun akademik 2016/2017 yang mengambil matakuliah Metode Numerik. Matakuliah prasyarat yang sudah ditempuh diantaranya adalah Kalkulus Diferensial, Kalkulus Integral, Kalkulus Lanjut, dan Persamaan Diferensial. Instrumen penelitian menggunakan lembar validasi untuk ahli materi, lembar validasi untuk ahli media, angket respon mahasiswa, dan soal tes.

Teknik analisis data yang digunakan adalah teknik analisis deskriptif kuantitatif, yaitu memaparkan hasil pengembangan media pembelajaran matakuliah Metode Numerik dengan implementasi Scilab berbantuan software Latex. Data kuantitatif yang diperoleh melalui lembar validasi dan angket respon mahasiswa kemudian diubah ke dalam bentuk kualitatif. Media pembelajaran matakuliah Metode Numerik dengan implementasi Scilab berbantuan software Latex dikatakan berkualitas jika dinilai "baik" atau "sangat baik" oleh ahli materi dan ahli media, serta memperoleh respon "baik" atau "sangat baik" dari mahasiswa.

Tabel 1 Kriteria Kategori Penilaian Ideal

\begin{tabular}{ccl}
\hline No. & Rentang Skor (i) Kuantitatif & Kategori \\
\hline 1 & $\bar{x}>M_{i}+S B_{i}$ & Sangat Baik \\
\hline 2 & $M_{i}<\bar{x} \leq M_{i}+S B_{i}$ & Baik \\
\hline 3 & $M_{i}-S B_{i}<\bar{x} \leq M_{i}$ & Kurang \\
\hline 4 & $\bar{x} \leq M_{i}-S B_{i}$ & Sangat Kurang \\
\hline
\end{tabular}

Keterangan:

$\bar{x}$ : Skor rata-rata

$M_{i}$ : rata-rata ideal, yaitu 2012).

${ }^{6}$ Sugiyono, Metode Penelitian Kuantitaf Kualitatif Dan R\&D (Bandung: Alfabeta, 


$$
\begin{aligned}
& M_{i}= \frac{1}{2} \text { (skor tertinggi ideal }+ \text { skor terendah ideal) } \\
& S B_{i}: \text { Simpangan baku ideal, yaitu } \\
& S B_{i}=\left(\frac{1}{2}\right)\left(\frac{1}{3}\right) \text { (skor tertinggi ideal }- \text { skor terendah ideal) } \\
& \text { Skor tertinggi ideal }=\sum \text { butir kriteria x skor tertinggi } \\
& \text { Skor terendah ideal }=\sum \text { butir kriteria } x \text { skor terendah }
\end{aligned}
$$

\section{Proses Pengembangan Media Pembelajaran}

\section{Tahap Define (Pendefinisian)}

Pada tahap ini diperoleh informasi tentang adanya teknologi yang dapat digunakan untuk membuat media pembelajaran pada matakuliah metode numerik. Teknologi tersebut berupa tersedianya software yang lisensinya gratis (freeware) yang dapat bersahabat dalam penulisan formula matematika, yaitu software Latex. Software ini sangat sesuai dengan karakteristik materi dalam matakuliah metode numerik yang banyak menggunakan berbagai formula matematika di dalamnya. Selain dalam penulisan formula matematika, peneliti juga menemukan kendala lain dalam penggunaan software yang digunakan dalam mencari penyelesaian berbagai persoalan numerik. Software yang digunakan selama ini memiliki beberapa kelemahan, di antaranya adalah memakan ruang yang besar pada PC atau laptop dan merupakan software yang lisensinya harus membayar. Permasalahan tersebut dapat diselesaikan dengan mengganti software yang ada dengan software baru yang memiliki fungsi sama, tidak memakan tempat pada PC ataupun laptop, dan lisensinya tidak membayar. Software tersebut adalah Scilab. Berdasarkan hal tersebut, maka dalam penelitian ini dikembangkan media pembelajaran dengan mengaplikasikan freeware yang sesuai (Latex dan Scilab).

Adapun media pembelajaran yang dikembangkan dalam penelitian ini berupa media visual bentuk bahan cetak (media yang tidak diproyeksikan) dan dalam bentuk file presentasi (media yang dapat diproyeksikan). Bahan cetak yang dimaksud dalam penelitian ini berupa handout matakuliah metode numerik pada materi mencari akar persamaan nonlinear. Sedangkan file presentasi yang dimaksud dalam penelitian ini adalah file presentasi yang bersesuaian dengan handoutyang dibuat.

Pada tahap ini juga dihasilkan beberapa hasil identifikasi terkait

dengan kompetensi dasar, karakteristik mahasiswa, kemampuan awal mahasiswa, serta tujuan pembelajaran dan indikator pencapaian hasil belajar.

\section{Tahap Design (Perancangan)}

Tahap perancangan dilakukan dalam beberapa langkah yang akan diuraikan tiap langkah. Langkah pertama, menyusun kebutuhan dalam 
pembuatan media pembelajaran sesuai dengan capaian pembelajaran (learning outcomes) matakuliah Metode Numerik dalam Kurikulum Kerangka Kualifikasi Nasional Indonesia). Pada langkah ini, peneliti mencermati kemampuan kerja yang diharapkan dapat dicapai oleh mahasiswa pada matakuliah Metode Numerik. Peneliti juga mencermati Rencana Pembelajaran Semester (RPS) pada matakuliah Metode Numerik. Langkah kedua, menyusun butir-butir materi yang disajikan dalam media pembelajaran sesuai dengan capaian pembelajaran yang diharapkan. Media pembelajaran yang dikembangakan dalam penelitian ini terdiri atas dua jenis, yaitu handout dan file presentasi. Keduanya dibuat dengan bantuan software Latex. Handout yang dikembangkan dalam penelitian ini terdiri atas dua bagian. Bagian pertama adalah motivasi yang berisi tentang motivasi perlunya belajar akar persamaan nonlinear, metode numerik, serta Scilab. Bagian kedua berisi beberapa solusi numerik dalam mencari akar persamaan nonlinear. Ada lima metode pencarian akar persamaan nonlinear yang dikaji dalam penelitian ini yaitu, Metode Biseksi, Metode Newton, Metode Sekan, Metode Posisi Palsu, dan Metode Titik Tetap. File presentasi dikembangkan berdasarkan handout yang telah dikembangkan. Langkah ketiga, yaitu pembuatan media pembelajaran yang meliputi penulisan naskah, script, dan tamplate pada text editor software Latex. Pada bagian penyelesaian numeriknya disusun program pada SciNotes sofware Scilab. Handout yang dikembangkan dilengkapi dengan halaman judul, daftar isi, lembar kerja mahasiswa, serta daftar pustaka. Berikut adalah salah satu script dalam penulisan halaman judul.

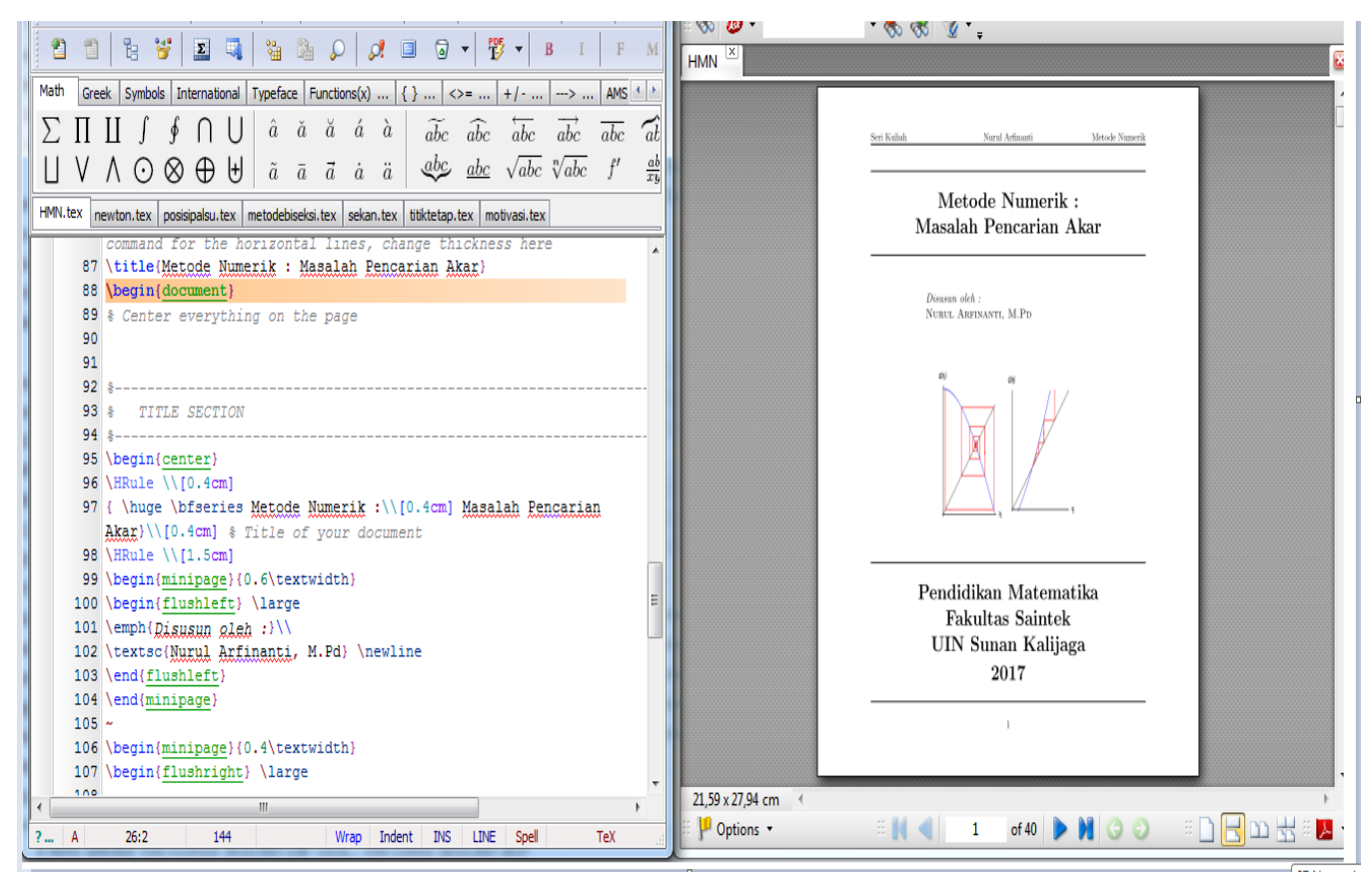

Gambar 1 Contoh Script Penulisan Halaman Judul 
Pada tahap ini juga dilakukan penulisan SciNotes untuk materi mencari akar persamaan nonlinear. Berikut adalah salah satu penulisan SciNotes pada media pembelajaran yang dikembangkan.

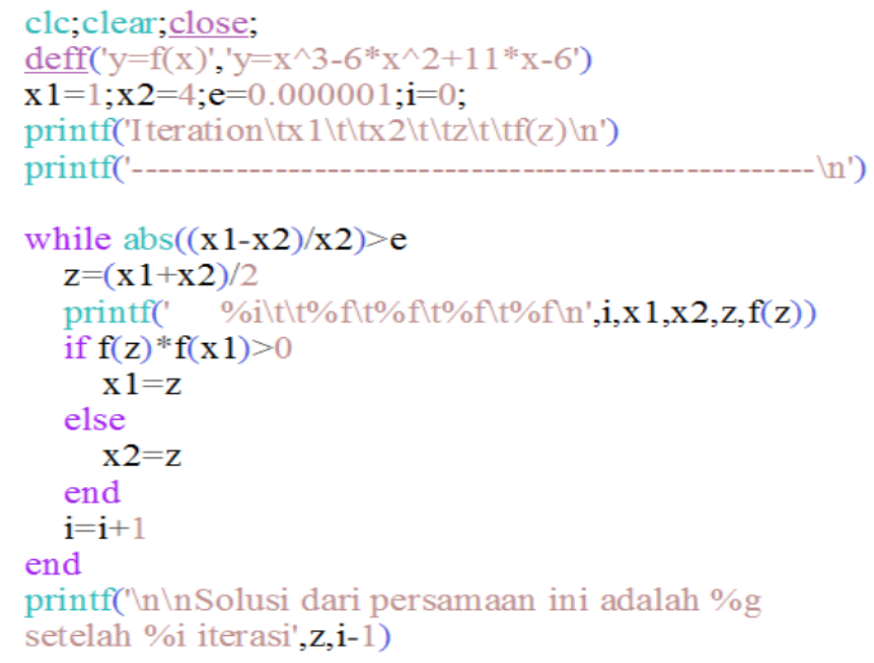

Gambar 2 SciNotes pada Metode Biseksi

\begin{tabular}{|c|c|c|c|c|}
\hline 0 & 1.000000 & 4.000000 & 2.500000 & -0.375000 \\
\hline 1 & 1.000000 & 2.500000 & 1.750000 & 0.234375 \\
\hline 2 & 1.000000 & 1.750000 & 1.375000 & 0.380859 \\
\hline 3 & 1.000000 & 1.375000 & 1.187500 & 0.276123 \\
\hline 4 & 1.000000 & 1.187500 & 1.093750 & 0.161957 \\
\hline 5 & 1.000000 & 1.093750 & 1.046875 & 0.087261 \\
\hline 6 & 1.000000 & 1.046875 & 1.023438 & 0.045240 \\
\hline 7 & 1.000000 & 1.023438 & 1.011719 & 0.023027 \\
\hline 8 & 1.000000 & 1.011719 & 1.005859 & 0.011616 \\
\hline 9 & 1.000000 & 1.005859 & 1.002930 & 0.005834 \\
\hline 10 & 1.000000 & 1.002930 & 1.001465 & 0.002923 \\
\hline 11 & 1.000000 & 1.001465 & 1.000732 & 0.001463 \\
\hline 12 & 1.000000 & 1.000732 & 1.000366 & 0.000732 \\
\hline 13 & 1.000000 & 1.000366 & 1.000183 & 0.000366 \\
\hline 14 & 1.000000 & 1.000183 & 1.000092 & 0.000183 \\
\hline 15 & 1.000000 & 1.000092 & 1.000046 & 0.000092 \\
\hline 16 & 1.000000 & 1.000046 & 1.000023 & 0.000046 \\
\hline 17 & 1.000000 & 1.000023 & 1.000011 & 0.000023 \\
\hline 18 & 1.000000 & 1.000011 & 1.000006 & 0.000011 \\
\hline 19 & 1.000000 & 1.000006 & 1.000003 & 0.000006 \\
\hline 20 & 1.000000 & 1.000003 & 1.000001 & 0.000003 \\
\hline 21 & 1.000000 & 1.000001 & 1.000001 & 0.000001 \\
\hline
\end{tabular}

Gambar 3 Hasil Eksekusi SciNotes pada Metode Biseksi

Hasil pada tahap design ini merupakan produk murni yang kemudian disebut sebagai draft 1 . Draft 1 berbentuk handout serta slide presentasi pada matakuliah metode numerik. Draft 1 kemudian divalidasi dan direvisi pada tahap selanjutnya. 


\section{Hasil pada Tahap Develop (Pengembangan)}

Pada tahap ini dilakukan validasi, revisi, dan ujicoba lapangan terbatas untuk menghasilkan produk akhir (media pembelajaran matakuliah Metode Numerik yang berkualitas). Draft 1 yang telah dihasilkan pada tahap design kemudian divalidasi oleh ahli materi dan ahli media dan dilakukan perbaikan sesuai masukan yang diperoleh untuk kemudian dihasilkan draft 2. Draft 2 kemudian diujicobakan secara terbatas untuk melihat respon mahasiswa serta capaian pembelajaran yang diperoleh menggunakan media pembelajaran yang telah dikembangakan. Media pembelajaran yang dikembangkan dikatakan berkualitas jika memperoleh penilaian minimal baik dari semua validator, memperoleh respon yang baik atau sangat baik dari mahasiswa, dan mahasiswa dapat memenuhi capaian pembelajaran yang telah ditentukan untuk matakuliah metode numerik (mahasiswa memperoleh minimal nilai 55). Berikut adalah rincian hasil pada tahap develop.

Tabel 2 Hasil Penilaian Media Pembelajaran Matakuliah Metode Numerik oleh Ahli Materi

\begin{tabular}{|c|c|c|c|c|c|c|}
\hline \multirow{2}{*}{ No } & \multirow{2}{*}{ Penilai } & \multicolumn{4}{|c|}{ Hasil Penilaian Tiap Aspek } & \multirow{2}{*}{ Total } \\
\hline & & Kelayakan Isi & Penyajian & Kebahasaan & Kegrafikan & \\
\hline 1 & Penilai 1 & 16 & 20 & 16 & 12 & 64 \\
\hline \multirow[t]{3}{*}{2} & Penilai 2 & 14 & 18 & 14 & 11 & 57 \\
\hline & alah & 30 & 38 & 30 & 23 & 121 \\
\hline & a-rata & 15 & 19 & 15 & 11,5 & 60,5 \\
\hline \multicolumn{2}{|c|}{ Persentase Keidealan } & 93,75 & 95 & 93,75 & 95,83 & 94,53 \\
\hline \multicolumn{2}{|c|}{ Kategori } & sangat baik & $\begin{array}{c}\text { sangat } \\
\text { baik }\end{array}$ & sangat baik & sangat baik & $\begin{array}{c}\text { sangat } \\
\text { baik }\end{array}$ \\
\hline
\end{tabular}

Berdasarkan validasi dari ahli materi seperti terlihat pada Tabel 2, diperoleh informasi bahwa media pembelajaran matakuliah Metode Numerik dengan implementasi Scilab berbantuan software Latex memperoleh penilaian sangat baik dalam setiap aspek penilaian. Aspek yang dinilai oleh ahli materi meliputi kelayakan isi, penyajian, kebahasaan, dan kegrafikan. Ahli materi yang menilai media pembelajaran matakuliah Metode Numerik dengan implementasi Scilab berbantuan software Latex merupakan orang yang expert di bidang materi metode numerik, yaitu dua orang dosen yang memiliki latar belakang keilmuan matematika murni dan expert di bidang metode numerik. 
Tabel 3 Hasil Penilaian Media Pembelajaran Matakuliah Metode Numerik oleh Ahli Media

\begin{tabular}{lccccc}
\hline \multirow{2}{*}{ No } & \multirow{2}{*}{ Penilai } & \multicolumn{3}{c}{ Hasil Penilaian Tiap Aspek } & \multirow{2}{*}{ Total } \\
\cline { 3 - 5 } & & Kelayakan Isi & Kebahasaan & Kegrafikan & \\
\hline 1 & Penilai 1 & 16 & 13 & 10 & 39 \\
\hline 2 & Penilai 2 & 19 & 14 & 11 & 44 \\
\hline Jumlah & 35 & 27 & 21 & 83 \\
\hline \multicolumn{2}{l}{ Rata-rata } & 17,5 & 13,5 & 10,5 & 41,5 \\
\hline Persentase & Keidealan & 87,5 & 84,375 & 87,5 & 86,46 \\
\hline \multicolumn{2}{l}{ Kategori } & sangat baik & sangat baik & sangat baik & sangat baik \\
\hline
\end{tabular}

Berdasarkan validasi dari ahli media seperti terlihat pada Tabel 3, diperoleh informasi bahwa media pembelajaran matakuliah Metode Numerik dengan implementasi Scilab berbantuan software Latex memperoleh penilaian sangat baik dalam setiap aspek penilaian. Aspek yang dinilai oleh ahli media meliputi kelayakan isi, kebahasaan, dan kegrafikan. Ahli media yang menilai media pembelajaran matakuliah Metode Numerik dengan implementasi Scilab berbantuan software Latex merupakan orang yang expert di bidang media pembelajaran, yaitu satu orang dosen yang mengampu matakuliah media pembelajaran dan satu orang dosen yang memiliki bidang keahlian teknologi pembelajaran.

Setelah dilakukan validasi oleh oleh ahli materi dan ahli media, kemudian dilakukan perbaikan sesuai dengan saran validasi dan dihasilkan draft 2. Draft 2 kemudian diujicobakan secara terbatas kepada mahasiswa untuk diketahui respon dan capaian pembelajarannya. Berikut adalah hasil respon mahasiswa terhadap media pembelajaran matakuliah Metode Numerik dengan implementasi Scilab berbantuan software Latex.

Tabel 4 Hasil Respon Mahasiswa Terhadap Media Pembelajaran Matakuliah Metode Numerik

\begin{tabular}{lccccc}
\hline \multirow{2}{*}{ No } & \multirow{2}{*}{ Penilai } & \multicolumn{3}{c}{ Hasil Penilaian Tiap Aspek } & \multirow{2}{*}{ Total } \\
\cline { 2 - 5 } & & Kelayakan Isi & Kebahasaan & Kegrafikan & \\
\hline 1 & Mahasiswa 1 & 16 & 12 & 12 & 40 \\
\hline 2 & Mahasiswa 2 & 16 & 12 & 12 & 40 \\
\hline 3 & Mahasiswa 3 & 13 & 12 & 9 & 34 \\
\hline 4 & Mahasiswa 4 & 15 & 10 & 12 & 37 \\
\hline 5 & Mahasiswa 5 & 15 & 12 & 10 & 37 \\
\hline 6 & Mahasiswa 6 & 12 & 9 & 8 & 29 \\
\hline 7 & Mahasiswa 7 & 15 & 11 & 11 & 37 \\
\hline 8 & Mahasiswa 8 & 12 & 9 & 9 & 30 \\
\hline 9 & Mahasiswa 9 & 15 & 11 & 10 & 36 \\
\hline 10 & Mahasiswa 10 & 15 & 10 & 12 & 37 \\
\hline 11 & Mahasiswa 11 & 15 & 9 & 12 & 36 \\
\hline
\end{tabular}




\begin{tabular}{ccccc}
\hline Jumlah & 159 & 117 & 117 & 393 \\
\hline rata-rata & 14,45 & 10,64 & 10,64 & 35,73 \\
\hline Persentase Keidealan & 90,31 & 88,67 & 88,67 & 89,325 \\
\hline Kategori & sangat baik & sangat baik & sangat baik & sangat baik \\
\hline
\end{tabular}

Berdasarkan Tabel 4 di atas dapat disimpulkan bahwa hasil respon mahasiswa untuk setiap aspek penilaian baik itu kelayakan isi, kebahasaan, dan kegrafikan memperoleh respon sangat baik dari mahasiswa. Selain respon mahasiswa, pada tahap ujicoba terbatas juga dilihat pencapaian mahasiswa terhadap capaian pembelajaran yang telah ditetapkan (mencari akar persamaan nonlinear). Berikut adalah soal yang digunakan pada tahap ujicoba.

SOAL :

1. Perhatikan grafik fungsi $f(x)=x^{2}-4 x+2$ berikut ini! Carilah salah satu akarnya dan tulislah metode (minimal dua metode berbeda) yang anda gunakan dalam menentukan akar tersebut!

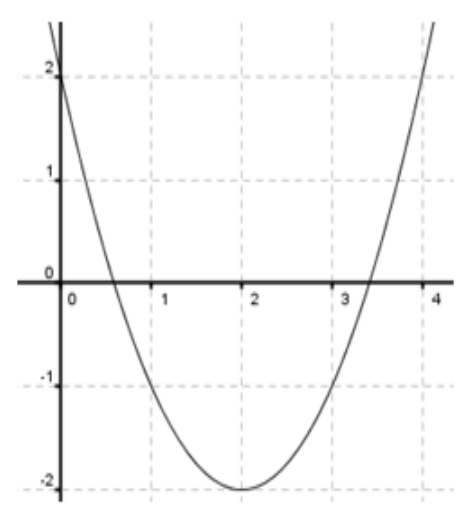

2. Ubahlah bentuk persamaan $\mathrm{x}^{3}-\mathrm{x}-1=0$ sedemikian hingga metode iterasi sederhana dapat digunakan untuk mendapatkan nilai akar dari persamaan tersebut!

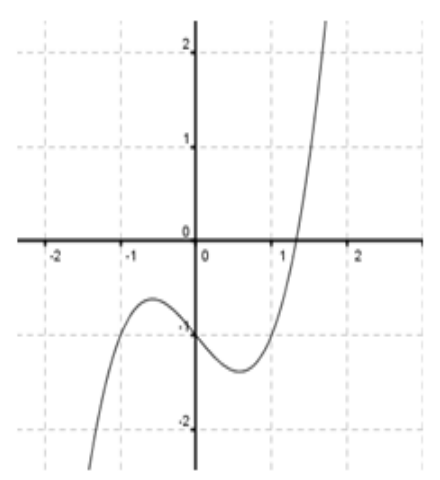

Gambar 4 Soal Tes Mencari Akar Persamaan Nonlinear

Berikut adalah hasil belajar mahasiswa pada capaian pembelajaran matakuliah metode numerik mencari akar persamaan nonlinear. 
Tabel 5 Hasil Belajar Mahasiswa pada Capaian Pembelajaran Matakuliah Metode Numerik Mencari Akar Persamaan Nonlinear

\begin{tabular}{ccc}
\hline No & Nama & Nilai \\
\hline 1 & Mahasiswa 1 & 78 \\
\hline 2 & Mahasiswa 2 & 88 \\
\hline 3 & Mahasiswa 3 & 75 \\
\hline 4 & Mahasiswa 4 & 100 \\
\hline 5 & Mahasiswa 5 & 65 \\
\hline 6 & Mahasiswa 6 & 75 \\
\hline 7 & Mahasiswa 7 & 85 \\
\hline 8 & Mahasiswa 8 & 75 \\
\hline 9 & Mahasiswa 9 & 90 \\
\hline 10 & Mahasiswa 10 & 93 \\
\hline 11 & Mahasiswa 11 & 65 \\
\hline
\end{tabular}

Berdasarkan Tabel 5 tersebut, dapat dilihat bahwa perolehan nilai mahasiswa semuanya berada di atas 55 (nilai minimal yang harus diperoleh mahasiswa agar dinyatakan lulus pada suatu capaian pembelajaran). Nilai yang paling rendah adalalah 65 dan ada dua orang mahasiswa yang memperoleh nilai tersebut. Sementara itu nilai tertingginya adalah 100 dan ada satu mahasiswa yang memperoleh nilai tersebut. Rata-rata dari nilai mahasiswa pada capaian pembelajaran matakuliah metode numerik mencari akar persamaan nonlinear adalah 80,82 (jika dikonversi huruf sesuai aturan UIN Sunan Kalijaga maka akan diperoleh nilai B+).

Pada tahapan akhir ini, kemudian dilihat dan dianalisis hasil keseluruhannya. Secara menyeluruh hasil pada tahap develop menunjukkan bahwa media pembelajaran matakuliah Metode Numerik dengan implementasi Scilab berbantuan software Latex sebagai media pembelajaran telah memenuhi kriteria kualitas yang telah ditetapkan. Hal tersebut dapat dilihat dari: (a) penilaian ahli materi yang mencakup aspek kelayakan isi, penyajian, kebahasaan, kegrafikan memperoleh persentase keidealan skor rata-rata 94,53, berada pada kategori sangat baik, (b) penilain ahli media yang mencakup aspek penyajian, kebahasaan, dan kegrafikan memperoleh persentase keidealan skor rata-rata 86,46 , berada pada kategori sangat baik, (c) respon mahasiswa terhadap media pembelajaran yang mencakup aspek kelayakan isi, kebahasaan, dan kegrafikan memperoleh persentase keidealan 89,325, berada pada kategori sangat baik, (d) hasil belajar mahasiswa pada capaian pembelajaran matakuliah Metode Numerik tentang akar persamaan nonlinear menunjukkan bahwa mahasiswa memperoleh nilai minimal 65 dengan nilai rata-rata keseluruhan 80,82. Atau dengan kata lain mahasiswa 
yang diujicoba telah memenuhi standar kelulusan matakuliah pada capaian pembelajaran tersebut.

\section{Hasil Penelitian}

Penelitian ini bertujuan untuk mengembangkan media pembelajaran matakuliah Metode Numerik berbantuan software Latex dengan implementasi Scilab yang berkualitas. Metode penelitian pengembangan yang digunakan dalam penelitian ini mengadopsi dari moderl pengembangan 3-D sehingga dihasilkan produk yang berkualitas. Media pembelajaran matakuliah Metode Numerik berbantuan software Latex dengan implementasi Scilab dikatakan berkualitas jika memenuhi kriteria kelayakan yang telah ditetapkan, yaitu memperoleh penilaian baik atau sangat baik dari ahli materi, ahli media, serta memperoleh respon baik atau sangat baik dari mahasiswa.

Berdasarkan hasil validasi dari ahli materi dan ahli media diperoleh informasi bahwa presentase keidealan skor rata-rata oleh ahli materi dan ahli media berturut-turut adalah 94,53 dan 86,46. Hal ini berarti media pembelajaran yang dikembangkan memiliki kualitas sangat baik dan layak digunakan dalam kegiatan pembelajaran. Hal ini dikarenakan dalam pembuatan media pembelajaran matakuliah metode numerik sangat memperhatikan kebutuhan mahasiswa dan karakteristik materi. Mahasiswa merasa termotivasi karena media pembelajaran yang digunakan juga menampilkan praktik dengan komputer tidak hanya berisi teori saja. Penyajian materi pada slide presentasi juga diatur sedemikian rupa sehingga tampilan yang dihasilkan menarik dan mudah dipahami. Walaupun demikian tetap dilakukan perbaikan berdasarkan masukan dari ahli materi dan ahli media.

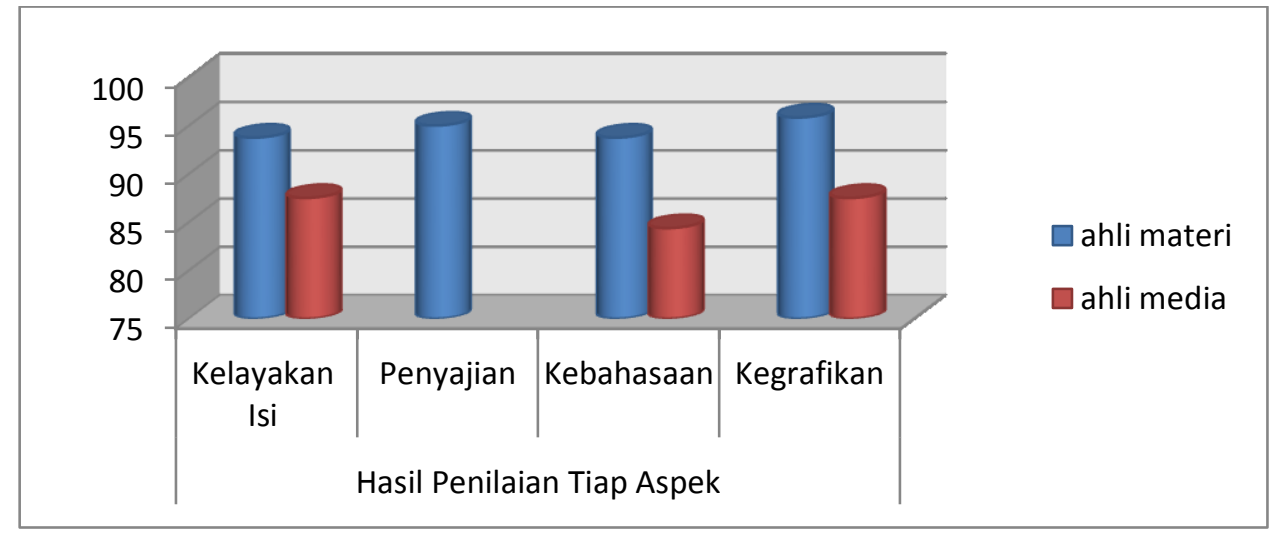

Gambar 5 Rekap Hasil Validasi dari Ahli Materi dan ahli Media

Berdasarkan hasil ujicoba terbatas terhadap 11 responden mahasiswa Prodi Pendidikan Matematika Fakultas Sains dan Teknologi Universitas Islam 
Negeri Sunan Kalijaga diperoleh persentase keidealan rata-rata skor 89,325 yang berarti media pembelajaran yang dikembangkan memperoleh respon sangat baik dari mahasiswa. Hasil ini juga menunjukkan bahwa media pembelajaran telah memenuhi kriteria kualitas yang telah ditetapkan. Respon mahasiswa terhadap media pembelajaran yang digunakan memiliki peranan yang penting dalam upaya menciptakan kegiatan pembelajaran yang efektif dan efisien. Respon positif dari mahasiswa terhadap media pembelajaran yang digunakan merupakan suatu tanda bahwa mahasiswa dapat mengikuti dan memperhatikan materi perkuliahan yang disampaikan. Respon yang positif juga menunjukkan bahwa mahasiswa memiliki ketertarikan terhadap media pembelajaran yang digunakan sehingga diharapkan pesan yang terkandung dalam media pembelajaran (dalam hal ini adalah materi perkuliahan) dapat diterima dengan baik oleh mahasiswa sebagai penerima pesan.

Ada beberapa hal yang menjadi catatan peneliti selama proses pengambilan data respon mahasiswa. Di antaranya adalah komentar dan saran dari mahasiswa yang menyatakan mereka sangat tertarik dengan penggunaan software baru khususnya dalam penyampaian materi matakuliah Metode Numerik. Apalagi software tersebut tersedia secara gratis dan tidak memakan tempat yang besar pada PC atau laptop mahasiswa. Hal ini dikarenakan sebagian besar laptop mahasiswa tidak memiliki kapasitas penyimpanan software yang besar. Perkembangan teknologi memang seharusnya dapat digunakan semaksimal mungkin untuk kegiatan pembelajaran. Hal ini sejalan dengan pendapat Sutarman yang mengatakan bahwa pengaruh teknologi informasi dan komunikasi dalam pendidikan untuk memecahkan masalah, membuka kreativitas, meningkatkan efektivitas, dan efisiensi dalam melakukan pekerjaan?.

Hasil penilaian penguasaan mahasiswa terhadap capaian pembelajaran matakuliah metode numerik menentukan akar persamaan non linear menunjukkan bahwa semua mahasiswa telah lulus. Hal ini berarti penggunaan media pembelajaran matakuliah Metode Numerik berbantuan software Latex dengan implementasi Scilab dapat mencapai capaian pembelajaran yang telah ditentukan. Dengan kata lain, penggunaan media ini efektif (tepat guna) untuk diterapkan pada pembelajaran matakuliah Metode Numerik. Hal ini sesuai dengan konsep pembelajaran tuntas pada Standar Nasional Perguruan Tinggi (SNPT).

Penggunaan model pembelajaran harus disesuaikan dengan karakteristik materinya. Karakteristik matakuliah Metode Numerik yang memerlukan banyak perhitungan matematis membuat mahasiswa

${ }^{7}$ Sutarman, Pengantar Teknologi Informasi (Jakarta: Bumi Aksara, 2009). 
memerlukan ruang tersendiri untuk menulis ${ }^{8}$. Ada banyak algoritma penyelesaian masalah secara numerik yang harus dipelajari oleh mahasiswa. Mahasiswa juga harus mempraktikkan algoritma tersebut dalam menyelesaikan permasalahan matematika. Pembelajaran matakuliah Metode Numerik dengan menggunakan bantuan handout sebagai salah satu media pembelajarannya dapat menjadikan suatu keuntungan tersendiri. Media pembelajaran dalam bentuk handout dapat dicorat-coret oleh mahasiswa. Dengan menggunakan handout, mahasiswa juga dapat fokus pada materi yang sedang dipelajari tanpa harus takut ketinggalan materi karena belum sempat mencatat penjelasan dosen. Handout juga membantu mahasiswa untuk belajar secara mandiri sebelum perkuliahan dimulai.

Dilihat dari segi cara penyajian materi dalam handout, media pembelajaran matakuliah Metode Numerik yang dikembangkan memberikan kesempatan kepada mahasiswa untuk berpikir dan menuliskan hasil pemikirannya sendiri. Kemampuan komunikasi matematis akan terlatih jika mahasiswa diberikan kesempatan untuk berpikir dan diberi ruang untuk menyampaikan hasil pemikirannya. Hal serupa juga disampaikan oleh Supandi, dkk melalui hasil penelitian mereka dengan judul peningkatan kemampuan komunikasi tertulis matematis melalui strategi Think-TalkWrite $^{9}$.

Media pembelajaran matakuliah Metode Numerik selain disajikan dalam bentuk handout, juga disajikan dalam bentuk slide presentasi. Slide presentasi digunakan untuk membantu dalam penyampaian materi matakuliah Metode Numerik sehingga lebih terencana dan terarah. Sedangkan handout dapat digunakan oleh mahasiswa untuk belajar di rumah secara mandiri. Mahasiswa dapat belajar materi metode numerik sesuai dengan kemampuannya masing-masing. Mahasiswa juga dapat mempelajari materi sebelum perkuliahan berlangsung dan dapat mempelajari kembali materi yang telah dipelajari secara mandiri. Kemampuan belajar secara mandiri sangat diperlukan mahasiswa dalam segala aspek kehidupan. Hal ini sejalan dengan pendapat Sadjati yang mengatakan bahwa salah satu peran bahan ajar adalah membantu potensi siswa untuk menjadi pelajar mandiri ${ }^{10}$. Artinya, dengan bahan ajar yang dapat dipelajarinya sendiri, kapan dan di mana pun siswa berada maka sedikit demi sedikit siswa akan terbiasa untuk mengarahkan dirinya sendiri dalam belajar. Hal ini memotivasi dirinya untuk

${ }^{8}$ Hasan Djidu and Jailani Jailani, "Developing Problem Based Calculus Learning Model," Jurnal Kependidikan: Penelitian Inovasi Pembelajaran 2, no. 1 (May 30, 2018): 68-84, https://doi.org/10.21831/jk.v2i1.12689.

9 Supandi Supandi, Dani Nur Rosvitasari, and Widya Kusumaningsih, "Improving Mathematical Written Communication Skills Through Think-Talk-Write Strategy," Jurnal Kependidikan: Penelitian Inovasi Pembelajaran 1, no. 2 (December 8, 2017), https://doi.org/10.21831/jk.v1i2.9928.

${ }^{10}$ I. D. Sadjati, Hakikat Bahan AJar (Jakarta: Universitas Terbuka, 2012). 
sadar akan kewajibannya sebagai siswa, yaitu pandai mengelola waktu sehingga semua materi pelajaran dapat dikuasai sepenuhnya dalam waktu yang telah ditentukan.

\section{Penutup}

\section{Simpulan}

Berdasarkan hasil penelitian dan pembahasan diperoleh simpulan bahwa media pembelajaran matakuliah Metode Numerik berbantuan software Latex dengan implementasi Scilab yang dikembangkan dapat dikatakan berkualitas. Kualitas kelayakan dapat dilihat dari hasil berikut ini: pertama, hasil penilaian ahli materi yang mencakup aspek kelayakan isi, penyajian, kebahasaan, kegrafikan memperoleh persentase keidealan skor rata-rata 94,53, berada pada kategori sangat baik. Kedua, hasil penilain ahli media yang mencakup aspek penyajian, kebahasaan, dan kegrafikan memperoleh persentase keidealan skor rata-rata 86,46, berada pada kategori sangat baik. Ketiga, hasil dari respon mahasiswa terhadap media pembelajaran yang mencakup aspek kelayakan isi, kebahasaan, dan kegrafikan memperoleh persentase keidealan 89,33, berada pada kategori sangat baik. Dan keempat, hasil belajar mahasiswa pada capaian pembelajaran matakuliah Metode Numerik tentang akar persamaan nonlinear memperoleh skor minimal 65 dengan nilai rata-rata keseluruhan 80,82. Dengan kata lain mahasiswa yang diujicoba telah memenuhi standar kelulusan matakuliah pada capaian pembelajaran tersebut.

\section{Saran}

Berdasarkan hasil yang diperoleh dalam penelitian ini, maka dapat disarankan sebagai berikut: (a) software Scilab tidak hanya dapat digunakan dalam komputasi numerik, tetapi juga dalam analisis data dan visualisasi grafik 2D dan 3D sehingga memungkinkan dilakukan penelitian lebih lanjut tentang pembuatan media pembelajaran pada matakuliah lain atau materi sekolah lain yang relevan, (b) dapat dilakukan pengembangan lebih lanjut terkait pengembangan media pembelajaran matakuliah Metode Numerik atau matakuliah lain dengan menggunakan software yang bervariatif, (c) penelitian pengembangan lebih lanjut juga dapat dilakukan dengan menggunakan software Latex, seperti pengembangan buku ajar, modul, dan lain sebagainya. (d) tahap ujicoba skala besar dan tahap diseminasi perlu dilakukan agar dapat diketahui kualitas media pembelajaran secara lebih komprehensif, dan (e) perlu dilakukan penelitian lebih lanjut tentang strategi pembelajaran inovatif yang sesuai dengan media pembelajaran matakuliah metode numerik dengan berbantuan software Latex dan Scilab sehingga hasil belajar mahasiswa pada matakuliah metode numerik dapat lebih bagus lagi. 


\section{Ucapan Terimakasih}

Ucapan terimakasih kami haturkan kepada Lembaga Penelitian dan Pengabdian Masyarakat (LPPM) UIN Sunan Kalijaga yang telah membiayai penelitian melalui dana penelitian tahun 2017. Selain itu ucapan terimakasih juga kami sampaikan kepada Fakultas Sains dan Teknologi, serta Prodi Pendidikan Matematika UIN Sunan Kalijaga Yogyakarta yang telah memberikan kesempatan seluas-luasnya untuk melakukan penelitian di lingkungan Fakultas sains dan Teknologi UIN Sunan Kalijaga Yogyakarta.

\section{Daftar Pustaka}

Djidu, Hasan, and Jailani Jailani. "Developing Problem Based Calculus Learning Model." Jurnal Kependidikan: Penelitian Inovasi Pembelajaran 2, no. 1 (May 30, 2018): 68-84. https://doi.org/10.21831/jk.v2i1.12689.

Maryatun, Maryatun. "Pengaruh Penggunaan Media Program Microsoft Powerpoint Terhadap Hasil Belajar Strategi Promosi Pemasaran Mahasiswa Semester 2 Program Studi Pendidikan Ekonomi Universitas Muhammadiyah Metro Tahun Ajaran 2014/2015." PROMOSI: Jurnal Program Studi Pendidikan Ekonomi 3, no. 1 (2015). https://doi.org/10.24127/ja.v3i1.139.

Sadjati, I. D. Hakikat Bahan AJar. Jakarta: Universitas Terbuka, 2012.

Sasongko, Setia Budi. Metode Numerik Dengan Scilab. Yogyakarta: Andi Offset, 2010.

Sobiruddin, Dindin. "Penerapan Software MATLAB Terhadap Kemampuan Menyelesaikan Masalah Numerik Mahasiswa Jurusan Pendidikan Matematika." Paradikma Jurnal Pendidikan Matematika 8, no. 1 (April 28, 2015). https://doi.org/10.24114/paradikma.v8i1.3349.

Sugiyono. Metode Penelitian Kuantitaf Kualitatif Dan R\&D. Bandung: Alfabeta, 2012.

Supandi, Supandi, Dani Nur Rosvitasari, and Widya Kusumaningsih. "Improving Mathematical Written Communication Skills Through Think-Talk-Write Strategy." Jurnal Kependidikan: Penelitian Inovasi Pembelajaran 1, no. 2 (December 8, 2017). https://doi.org/10.21831/jk.v1i2.9928.

Sutarman. Pengantar Teknologi Informasi. Jakarta: Bumi Aksara, 2009.

Suyantiningsih, Isniatun Munawaroh, and Sisca Rahmadona. "Pengembangan Multimedia Pembelajaran Berbasis Scientific Approach Terintegrasi Nilai Karakter Untuk Siswa Sekolah Dasar Di Yogyakarta." Jurnal Kependidikan: Penelitian Inovasi Pembelajaran 46, no. 1 (July 21, 2016): 1-13. https://doi.org/10.21831/jk.v46i1.9571.

Suyoso, Suyoso, and Sabar Nurohman. "Pengembangan Modul Elektronik Berbasis Web Sebagai Media Pembelajaran Fisika." Jurnal Kependidikan: Penelitian Inovasi Pembelajaran 44, no. 1 (June 6, 2014). https://doi.org/10.21831/jk.v44i1.2193. 